\title{
PEMODELAN DISTRIBUSI TINGKAT IMBAL HASIL INDEKS HARGA DI TUJUH BURSA ASIA
}

Vol. 14 - No. 1

April 2014

\author{
Brady Rikumahu ${ }^{1}$
}

\section{ABSTRACT}

This paper examines the return distributions of 7 markets in the Asian region, namely Hongkong, Indonesia, Malaysia, Korea, Japan, Shanghai, and Singapore, to find out whether the return distributions in those markets follow a specific distribution. Using data from January 2000 to September 2009, the return distributions of each market were constructed and was first fitted to the normal distribution to find out whether or not each market behaves according to the standard theory of finance and investment - which stated that the financial time series follow a random walk - and thus would fit the normal distribution. The result of fitting the return distributions of the 7 markets to normal distribution shows that none of the return distributions follows the normal distribution as evident from the leptokurtic phenomena marked by the excess kurtosis compared to the normal distribution curve and also from the fatter than normal distribution tails and the existence of returns that lie outside the area predictedby the normal distribution.The return distributions were then fitted to a series of theoretical probability distribution. Each of the distribution was fitted to the theoretical. The results are: the Hongkong and Shanghai markets follow the Laplace distribution while the other five markets: Indonesia, Malaysia, Korea, Japan, and Singapore follow the Johnson SU distribution.

Keywords: Return Distribution, Laplace Distribution, Johnson SU Distribution

\section{PENDAHULUAN}

Salah satu hal penting yang berlaku dalam bidang investasi adalah kenyataan bahwa tingkat imbal hasil dari suatu investasi akan selalu berhubungan dengan risiko yang harus ditanggung oleh investor dalam melakukan investasi tersebut. Tingkat imbal hasil dari suatu investasi dapat didekati dengan menggunakan rata-rata dari tingkat imbal hasil yang pernah terjadi. Karena itu, pengetahuan yang tepat mengenai bagaimana perilaku tingkat imbal hasil yang sudah pernah terjadi akan sangat penting. Dengan mengetahui perilaku tingkat imbal hasil dimasa lalu, akan didapat kecenderungan tingkat imbal hasil dari investasi yang sedang berjalan dan berapa besar kemungkinan tingkat imbal hasil itu tidak tercapai.Dengan demikian dapat diketahui risiko yang harus ditanggung oleh investor.

Bachelier (1900) menemukan bahwa harga-harga komoditas berfluktuasi secara acak. Hasil ini ditemukan juga oleh Working (1934) saat melakukan analisis runtun waktu, dan juga oleh Kendall (1953) yang tidak dapat menemukan suatu pola yang pasti dalam pengujian indeks sekuritas dan harga-harga komoditas. Berdasar model Bachelier (1900), Working (1934), dan Kendall (1953) tersebut, perubahan harga suatu asset akan mengikuti variasi acak independen 
yang dikenal dengan istilah gerak Brown dimana harga suatu asset pada suatu saat tertentu adalah harga asset tersebut pada saat sebelumnya ditambah dengan suatu perubahan acak.

JURNAL MANAJEMEN INDONESIA

Vol. 14 - No. 1 April 2014
Osborne (1959) menyatakan bahwa jika perubahan harga dari satu transaksi ke transaksi lainnya merupakan variabel acak yang independen dan terdistribusi secara identik, memiliki varians yang terbatas dan transaksinya terdistribusi secara seragam dalam waktu, maka teorema limit sentral (Central Limit Theorem) akan memastikan bahwa perubahan harga pada suatu interval tertentu akan terdistribusi secara normal. Dengan kata lain, jika jumlah transaksinya bertambah besar, maka agregasi variabel acak yang berhubungan dengan perubahan harga akan menyebabkan variabel acak yang terjadi mengikuti hukum probabilitas normal. Kondisi ini membawa pengaruh penting: jika tingkat imbal hasil yang terjadi mengikuti distribusi normal maka hanya ada dua ukuran penting dari teorema limit sentral yang harus diketahui yaitu rata-rata yang merupakan ekspektasi tingkat imbal hasil - menunjukkan perkiraan berapa tingkat imbal hasil yang akan didapat - dan variansnya yang menunjukkan berapa besar risiko: kecenderungan suatu tingkat imbal hasil menyimpang dari ekspektasinya, dan dalam penggunaannya diwakili oleh deviasi standar yang merupakan akar dari varians.

Namun demikian, penggunaan distribusi normal hanya dapat digunakan jika informasi tiba di pasar secara linier dan investor bereaksi secara linier. Pengamatan di pasar menunjukkan bahwa tingkat imbal hasil tidak mengikuti distribusi normal. Mandelbrot (1963) melakukan pengujian terhadap varians sampel yang terdiri dari tingkat imbal hasil harga-harga kapas dan temuannya adalah bahwa varians dari tingkat imbal hasil komoditi tersebut tidak berkonvergensi ke suatu nilai yang terbatas, namun bergerak secara tidak teratur dan menunjukkan varians yang tidak terbatas (infinite). Berdasarkan hal tersebut Mandelbrot menyimpulkan bahwa perubahan harga dapat ditunjukkan oleh distribusi Paretian yang stabil atau bersifat leptokurtik. Temuan Mandelbrot (1963) ini didukung oleh penelitian Fama (1965) yang menguji tingkat imbal hasil dari 30 saham yang termasuk dalam Dow Jones Industrial Average. Berdasarkan hasil tersebut, Fama (1965) menyatakan bahwa tingkat imbal hasil dari investasi saham lebih berisiko daripada risiko yang diindikasikan oleh deviasi standar di distribusi normal. Namun demikian, Clark (1973) menemukan bahwa besaran perubahan harga asset akan tergantung pada besaran harganya namun tetap memiliki varians yang terbatas (finite). Berdasarkan Clark (1973), perubahan harga asset akan mengikuti distribusi lognormal dan akan lebih cocok dengan data dibandingkan dengan distribusi Paretian yang stabil. Selanjutnya, Peters (1991) dengan menggunakan data mingguan data mingguan untuk periode 1928-1989 menemukan bahwa tingkat pengembalian saham-saham yang termasuk dalam S\&P500 menunjukkan kemencengan negatif (negative skewness), ekor tebal (fat tails) dan puncak yang tinggi (high peak). Temuan Peters (1991) lainnya adalah probabilitas kejadian yang berjarak 3 deviasi standar dari rata-rata secara umum adalah dua kali lebih besar dari pada yang diperkirakan berdasar distribusi normal.

Penyimpangan dari distribusi normal akan memberikan implikasi yang penting: jika ternyata distribusi tingkat imbal hasil tidak mengikuti distribusi normal maka, selain rata-rata dan deviasi standar harus juga dihitung kemencengan dan kurtosis. Kemencengan menunjukkan keadaan dimana distributsi tingkat imbal hasil tidaksimetris dan dengan demikian ada kecenderungan masih terdapat kemungkinan adanya tingkat imbal hasil diluar dari kemungkinan yang diramalkan oleh distribusi normal sementara kurtosis menunjukkan bahwa data tingkat imbal hasil cenderung lebih runcing (leptokurtik) atau lebih datar (platikurtik) daripada data yang mengikuti distribusi normal. Selain itu, ekor dari distribusi yang memiliki kurtosis adalah tebal (fat tails) yang menunjukkan bahwa kemungkinan mendapatkan hasil yang di luar perkiraan distribusi normal cukup tinggi.

Dengan kata lain, jika distribusi tingkat imbal hasil mengikuti distribusi normal maka kemungkinan terjadinya tingkat imbal hasil dengan besaran diluar batas 3 deviasi standar diatas maupun dibawah rata-rata tingkat imbal hasil akan sangat kecil karena berdasarkan distribusi 
normal, probabilitas terjadinya tingkat imbal hasil dengan besaran diluar batas 3 deviasi standar di atas maupun di bawah rata-rata adalah mendekati nol namun, jika ternyata distribusi tingkat imbal hasil tidak mengikuti distribusi normal, akan mungkin terjadi tingkat imbal hasil diluar batas tersebut.

Makalah ini dimaksudkan untuk menjawab beberapa pertanyaan. Pertanyaan pertama yang ingin dijawab adalah seperti apa distribusi tingkat imbal hasil indeks di beberapa bursa di Asia. Sepanjang pengetahuan penulis, penentuan distribusi tingkat imbal hasil dari berbagai bursa di Asia belum banyak dilakukan, terutamayang melakukannya untuk lebih dari satu bursa sekaligus.Berdasarkan pandangan penulis, memahami distribusi tingkat imbal hasil yang tepat akan membantu dalam melakukan investasi. Dengan mengetahui distribusi tingkat imbal hasil yang tepat akan diketahui ekspektasi dari tingkat imbal hasil beserta besaran risiko yang harus dihadapi oleh investor.

Dalam hal ini pertama-tama dilakukan pengukuran tingkat imbal hasil dari indeks di tujuh bursa di Asia dan kemudian dibuat distribusi tingkat imbal hasil untuk masing-masing bursa. Selanjutnya dilakukan pencocokan antara distribusi tingkat imbal hasil yang didapat dengan distribusi teoretis. Pencocokan distribusi tingkat imbal hasil ini pada awalnya dilakukan dengan distribusi normal untuk mengetahui apakah distribusi tingkat imbal hasil di ketujuh bursa mengikuti distribusi normal seperti yang dinyatakan oleh Bachelier (1900), Working (1934), dan Kendall (1953). Karena distribusi tingkat imbal hasil di ke tujuh bursa tersebut tidak mengikuti distribusi normal, maka ketujuh distribusi tingkat imbal hasil tersebut dibandingkan dengan berbagai distribusi teoretis yang dikenal dan didapatkan bahwa untuk bursa Hongkong dan Shanghai, distribusi tingkat imbal hasilnya adalah mengikuti distribusi Laplace dan untuk bursa-bursa Indonesia, Malaysia, Korea, Jepang, dan Singapura distribusi tingkat imbal hasilnya mengikuti distribusi Johnson SU.

\section{KAJIAN PUSTAKA}

Aplikasi dari analisis data runtun waktu pada umumnya menggunakan asumsi bahwa data yang ada terdistribusi secara normal. Namun demikian, berdasarkan pengamatan, distribusi tingkat imbal hasil cenderung memiliki nilai-nilai yang ekstrim dan karena itu tidak mengikuti distribusi normal. Distribusi tingkat imbal hasil yang tidak mengikuti distribusi normal cenderung memiliki kemencengan, kurtosis, dan memiliki ekor tebal (heavy tailed). Cont (2001) mengklasifikasikan distribusi tingkat imbal hasil dari berbagai literatur ke dalam beberapa kelompok dengan beberapa diantaranya adalah: (i) distribusi stabil (Mandelbrot, 1963; McCulloch 1996), (ii) distribusi Student, (Kon, 1984), (iii) Normal inverse Gaussian - bagian dari Generalized Hyperbolic Distribution (Eberlein dan Keller 1995;Barndorff-Nielsen (1997), dan (iv) Exponentially truncated stable distribution, (Cont R, et al, 1997).

Selain berdasarkan klasifikasi oleh Cont (2001), terdapat berbagai distribusi probabilitas lain yang sering dihubungkan dengan bidang ekonomi maupun keuangan. Yan (2005) menunjukkan beberapa distribusi lain yang umum seperti Generalized Error Distribution (Nelson, 1991), distribusi Gram-Charlier (Jondeau dan Rockinger 2001), dan noncentral $t$ distribution (Harvey dan Siddique 1999). Selain itu, beberapa distribusi simetris dapat dibuat dibuat menjadi menceng (antara lain oleh Fernández dan Steel, 1998; Azzalini dan Capitanio 2003; serta Jones dan Faddy 2003).Secara umum Cont (2001) menyatakan bahwa agar suatu model parametrik dapat menreproduksi seluruh perilaku dari distribusi tingkat imbal hasil, maka model tersebut harus memiliki paling tidak empat parameter: (i) parameter lokasi, (ii) parameter skala (volatilitas), (iii) parameter yang menunjukkan peluruhan ekor, dan (iv) parameter asimetri yang menggambarkan perilaku yang berbeda dari ekor sebelah kiri dan sebelah kanan.

Gambar 3 Konsumsi Semen Domestik vs Pertumbuhan GDP 2002-2011 
Berdasarkan Yan (2005), setiap distribusi memiliki kekurangannya. Beberapa contohnya adalah: Generalized Error Distribution tidak memiliki ekor yang cukup tebal untuk mencakup kejadian-kejadian ekstrim, Generalized Hyperbolic Distribution akan sulit dihitung karena densitasnya memiliki suatu fungsi Bessel jenis ketiga dan memiliki tiga - bukan dua - parameter bentuk,distribusi Gram-Charlier hanya dapat menangani rentang kemencengan dan kurtosis yang kecil dan batasan nonlinear dari parameter-parameter bentuknya menyulitkan dalam estimasi, densitas dari noncentral distribution melibatkan penjumlahan dari seri yang tidak terbatas dan sulit untuk ditangani, dan suatu distribusi stabil tidak memiliki varians pada saat ekornya lebih tebal dari pada normal.

\section{Distribusi Laplace}

Distribusi Laplace - seringkali juga disebut sebagai double exponential distribution karena dapat dipandang sebagai dua buah distribusi eksponensial identik yang dipasangkan dengan posisi saling membelakangi - ditemukan oleh Laplace pada tahun 1774. Distribusi ini memiliki fungsi likelihood yang maksimal dengan mengatur parameter lokasi menjadi sama dengan median dari suatu nilai observasi yang berasal dari variabel acak berjumlah ganjil yang independen dan terdistribusi secara identik. Distribusi ini pertama kali terdapat pada makalah Laplace yang fundamental mengenai distribusi simetris untuk menjelaskan pengukuran kesalahan (error) dan seringkali dikenal sebagai hukum Laplace pertama dan (Johnson, Kotz, dan Balakrishnan, 1995; Balakrishnan dan Nevzorov, 2003)

Fungsi distribusi probabilitasnya adalah sebagai berikut:

$$
p_{X}(x)=\frac{1}{2 \lambda} \exp \left(-\frac{|x-\mu|}{\lambda}\right)
$$

dimana $\mu$ adalah parameter lokasi dan $\lambda$ adalah parameter skala, seringkali disebut sebagai diversity dengan besaran $\geq 0$. Nilai $x$ memiliki rentang dari $-\infty$ sampai dengan $+\infty$. Jika $\mu=0$ dan $\lambda=1$ maka akan tepat didapat sebuah distribusi eksponensial positif dengan skala $1 / 2$.

Distribusi Laplace adalah distribusi yang simetris dengan median pada $\mu$ nya, memiliki varians $=2$, dengan kemencengan sebesar 0 dan ekses kurtosis sebesar 3 yang menunjukkan bahwa distribusi ini memiliki ekor yang lebih tebal dari distribusi normal. Jika distribusi ini digeser, maka yang berubah adalah $\mu$ nya sementara semua parameter yang lain akan tetap.

Untuk bidang keuangan, Mittnik dan Rachev (1993) menggunakan distribusi Laplace untuk memodelkan distribusi unconditional untuk tingkat imbal hasil dari asset sementara penggunaan distribusi Laplace dalam konteks pemodelan GARCH dilakukan oleh Granger dan Ding (1995) untuk index S\&P 500 serta Gonzalez-Rivera (1997). Selain itu, Mittnik, Paolella, danRachev (1998) menggunakan distribusi Laplace untuk memodel distribusi unconditionaldan conditionaldari indeks Nikkei

\section{Distribusi Johnson SU}

Distribusi Johnson SU (Special Unbounded) adalah salah satu bagian dari keluarga distribusi yang diusulkan oleh Johnson (1949) untuk mengatasi masalah dalam menentukan distribusi yang tidak diketahui dari suatu variabel acak kontinyu. Johnson (1949) menurunkan suatu sistem kurva yang fleksibel untuk mencakup berbagai bentuk distribusi. Sistem yang dikembangkan Johnson (1949) berasal dari ide untuk menentukan distribusi yang sesuai dengan 
mengidentifikasi carayang sesuai untuk mentransformasi distribusi yang tidak diketahui tersebut menjadi distribusi normal standar $(N \sim(0,1))$. Secara umum hubungan antara distribusi yang ingin diketahui dengan distribusi normal standar akan memiliki bentuk umum sebagai berikut:

$$
\left(\frac{Z-\gamma}{\delta}\right)=g\left(\frac{X-\xi}{\lambda}\right)
$$

JURNAL

MANAJEMEN

INDONESIA

Vol. 14 - No. 1 April 2014

Dimana $Z$ adalah distribusi normal standar, parameter $\xi$ menentukan lokasi dari distribusi, $\lambda$ menentukan skala, vadalah kemencengan, dan $\delta$ adalah kurtosis dengan $\xi$ dan $\gamma$ adalah bilangan nyata sementara $\lambda$ dan $\delta$ harus lebih besar dari 0 . Dengan memiliki empat parameter, keluarga distribusi ini sangat fleksibel dan cocok dengan sebagian besar densitas empiris dengan sangat baik, asalkan distribusi yang dicocokkan adalah leptokurtik.

Untuk mentransformasi variabel acak yang kontinyu menjadi distribusi normal standar, persamaan di atas diatur ulang menjadi:

$$
z=\gamma+\delta g\left(\frac{X-\xi}{\lambda}\right)
$$

Dengan sistem ini, bentuk dari fungsi $g(u)$ ditentukan oleh kemencengan dan kurtosis dan dengan demikian, untuk memperkirakan suatu distribusi yang tidak diketahui, hanya perlu menemukan nilai $\xi, \lambda, \nu$, dan $\delta$ yang akan memberikan kesesuaian antara momen dari suatu distribusi yang tidak diketahui dengan besaran yang sesuai dari keluarga sistem Johnson. Keluarga sistem Johnson memiliki 4 bentuk sesuai dengan besaran $g(u)$ sebagai berikut:

$$
g(u)= \begin{cases}\ln [u /(1-u)] & \text { untuk keluarga bounded(SB) } \\ \sinh h^{-1} & \text { untuk keluarga unbounded(SU) } \\ \ln (u) & \text { untuk keluarga lognormal (SL) } \\ U & \text { untuk keluarga normal }\end{cases}
$$

Untuk keluarga yang bounded, kelompok distribusinya akan memiliki batasan yang pasti pada ekor bawah, atas, atau keduanya. Keluarga yang unbounded adalah distribusi yang dapat kedua ekornya dapat mencapai jarak yang tidak terhingga. Keluarga lognormal adalah bentuk yang berada di antara distribusi yang bounded dan unbounded. Keluarga normal adalah kasus khusus dari keluarga unbounded

Sistem yang dikembangkan oleh Johnson ini dapat mencakup rentang kemencengan dan kurtosis yang maksimum sehingga untuk setiap pasangan kemencengan dan kurtosis yang memenuhi syarat besarannya, akan ada satu distribusi yang sesuai dengan besaran kemencengan dan kurtosis yang sama.

Distribusi Johnson SU, dengan demikian, memiliki dua parameter bentuk yang memungkinkan untuk dicocokkan dengan rentang kemencengan dan kurtosis yang dapat ditemukan pada data tingkat imbal hasil finansial. Sebagai akibatnya, ekor dari distribusi ini tidak terlalu tebal.

Seperti yang sudah digambarkan pada bentuk umumnya, hubungan antara distribusi normal dengan distribusi Johnson SU adalah sebagai berikut:

$$
\left(\frac{Z-\gamma}{\delta}\right)=\sinh ^{-1}\left(\frac{X-\xi}{\lambda}\right)
$$


JURNAL

MANAJEMEN

INDONESIA

Vol. 14 - No. 1

April 2014 dimana $\sinh ^{-1}$ adah fungsi invers dari sinus hiperbola, dan dengan demikian, transformasinya menjadi distribusi normal adalah sebagai berikut:

$$
Z=\gamma+\delta \sinh ^{-1}\left(\frac{X-\xi}{\lambda}\right)
$$

\section{METODE PENELITIAN}

Penelitian ini terdiri dari beberapa tahapan: tahapan pertama adalah penentuan tingkat imbal hasil indeks harga saham dari bursa-bursa Hongkong, Indonesia, Malaysia, Korea, Jepang, Shanghai, dan Singapura. Tahapan kedua adalah membuat distribusi tingkat imbal hasil dari tiap bursa dan mencocokkan setiap distribusi dengan distribusi normal dan kemudian mencocokkan distribusi tingkat imbal hasil setiap bursa dengan berbagai distribusi teoretis.

\section{Penentuan tingkat imbal hasil indeks harga saham dari 7 bursa yang diteliti}

Perhitungan tingkat imbal hasil dilakukan untuk bursa-bursa Indonesia, Cina (Shanghai), Jepang, Korea, Hongkong, Malaysia, dan Singapura. Data yang dipakai diambil dari Yahoo! Finance dalam bentuk data penutupan harian indeks setiap Negara mulai dari 4 Januari 2000 sampai dengan 31 September 2012.

Perhitungan tingkat imbal hasil setiap bursa dilakukan dengan menggunakan pendekatan continuous dan dengan demikian menggunakan persamaan sebagai berikut:

$$
r_{t}=\ln \left(P_{t} / P_{t-1}\right)
$$

dimanar ${ }_{t}$ adalah tingkat imbal hasil suatu bursa tertentu pada waktu $t, \mathrm{P}_{t}$ adalah besaran indeks harga bursa tersebut pada waktu t, dan $\mathrm{P}_{\mathrm{t}-1}$ besaran indeks harga bursa tersebut pada waktu $\mathrm{t}-1$.

Tahapan kedua adalah membandingkan distribusi tingkat imbal hasil indeks dari ke 7 negara tersebut dengan distribusi normal. Pada tahapan ini perbandingan dilakukan dengan cara membandingkan grafik distribusi normal dengan grafik distribusi tingkat imbal hasil dari setiap bursa.

Tahapan ketiga adalah mencari distribusi yang sesuai dengan distribusi teoritis yang sesuai dengan melakukan pengujian kesesuaian distribusi.

\section{HASIL ANALISIS}

\section{Statistik deskriptif}

Statistik deskriptif untuk ke tujuh bursa yang meliputi jumlah pengamatan, rata-rata tingkat imbal hasil, deviasi standar dari tingkat imbal hasil, tingkat imbal hasil maksimal dan minimal dapat dilihat pada Tabel 1:

\begin{tabular}{|l|r|r|r|r|r|r|r|}
\hline & Hongkong & Indonesia & Malaysia & \multicolumn{1}{c|}{ Korea } & \multicolumn{1}{c|}{ Jepang } & \multicolumn{1}{c|}{ Shanghai } & \multicolumn{1}{c|}{ Singapura } \\
\hline Jumlah & 3180 & 3086 & 3139 & 3145 & 3128 & 3268 & 3256 \\
\hline Rata-rata & $0.006 \%$ & $0.059 \%$ & $0.026 \%$ & $0.020 \%$ & $-0.024 \%$ & $0.013 \%$ & $0.005 \%$ \\
\hline Std Dev & $1.631 \%$ & $1.497 \%$ & $1.151 \%$ & $1.764 \%$ & $1.576 \%$ & $1.596 \%$ & $1.263 \%$ \\
\hline R-maks & $13.407 \%$ & $7.623 \%$ & $19.861 \%$ & $11.284 \%$ & $13.235 \%$ & $9.401 \%$ & $7.531 \%$ \\
\hline R-min & $-13.582 \%$ & $-10.954 \%$ & $-19.246 \%$ & $-12.805 \%$ & $-12.111 \%$ & $-9.256 \%$ & $-9.216 \%$ \\
\hline
\end{tabular}


Berdasar Tabel 1 dapat terlihat bahwa jumlah hari di masing-masing bursaselama masa pengamatan adalah berbeda dimana hari perdagangan terbanyak terdapat di Shanghai (3.268 hari) sementara hari perdagangan terendah terdapat di bursa Indonesia (3086 hari). Untuk tingkat imbal hasil harian rata-rata yang tertinggi adalah Indonesia sebesar 0,059\% sementara terendah adalah Jepang $(-0,024 \%)$. Untuk deviasi standar, nilai deviasi standar harian tertinggi terdapat pada bursa Korea (1,764\%) dan terendah adalah di Malaysia (1,151\%). Deviasi standar di bursa Indonesia, yang memiliki tingkat imbal hasil harian tertinggi, berada pada urutan ke-lima sebesar 1,497\% dari ketujuh bursa yang diamati. Tingkat imbal hasil harian tertinggi $(19,861 \%)$ adalah di bursa Malaysia diikuti oleh $+13,41$ di bursa Hongkong sementara tingkat imbal hasil harian terendah $(-19,25 \%)$ terdapat di bursa Malaysia diikuti oleh bursa Hongkong sebesar $-13,58 \%$.

\section{Gambaran mengenai Pergerakan Harga dan Tingkat Imbal Hasil}

Gambaran mengenai pergerakan harga di setiap bursa selama masa pengamatan dapat dilihat pada Grafik 1. Dari grafik tersebut dapat dilihat bahwa seluruh bursa mengalami penurunan indeks harga yang tajam pada tahun 2008 saat terjadi krisis subprime mortgage di Amerika Serikat -sampai dengan sekitar $50 \%$ sampai $60 \%$ dari nilai sebelum krisis-dan kemudian meningkat kembali setelah tahun 2009 dengan peningkatan tertinggi sampai dengan akhir September 2012 terdapat di bursa Indonesia sebesar kurang lebih 300\%. Secara umum dapat dikatakan bahwa selama masa pengamatan indeks harga di bursa Jepang cenderung memiliki trend menurun dan di Shanghai cenderung memiliki trend menyamping sementara untuk ke-5 bursa sisanya cenderung memiliki trend meningkat.

Indeks harga saham bursa Hongkong

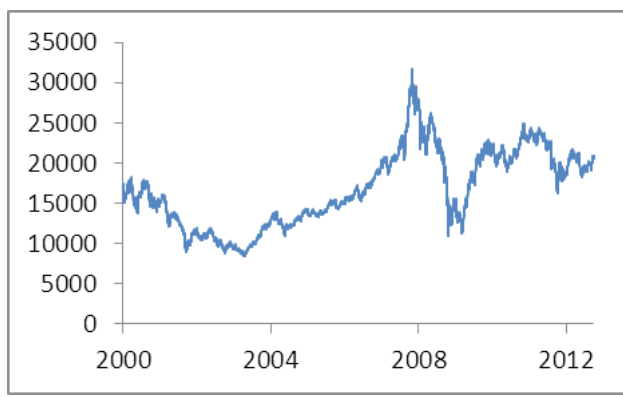

Indeks harga saham bursa Malaysia

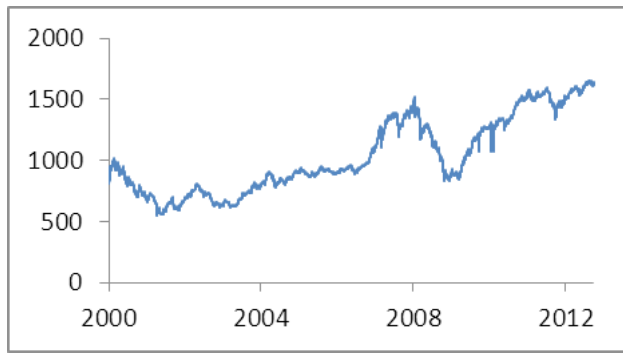

Indeks harga saham bursa Indonesia

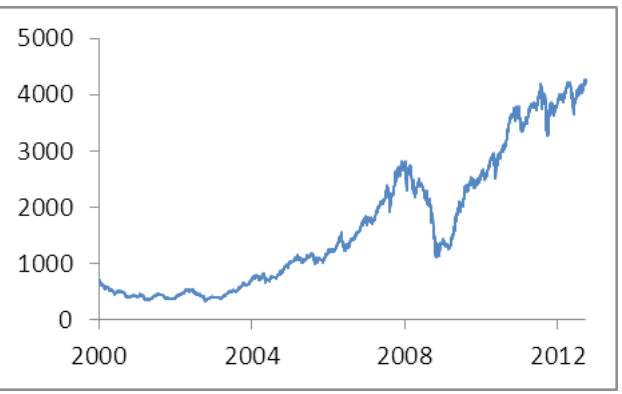

Indeks harga saham bursa Korea

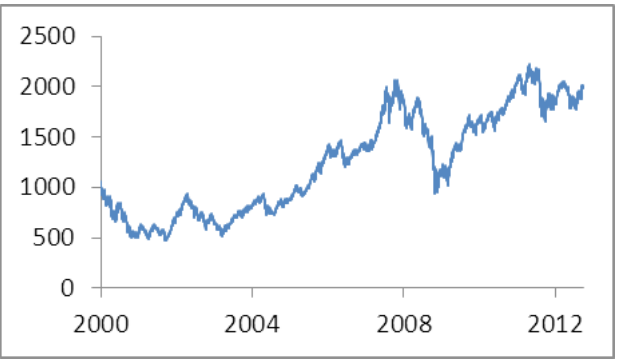

JURNAL

MANAJEMEN

INDONESIA

Vol. 14 - No. 1 April 2014
Grafik 1

Indeks Harga di BursaBursa yang Diteliti 
ndeks harga saham bursa Jepang

JURNAL

MANAJEMEN INDONESIA

Vol. 14 - No. 1

April 2014
Grafik 2

Tingkat Imbal Hasil Saham di Bursa-Bursa yang Diteliti
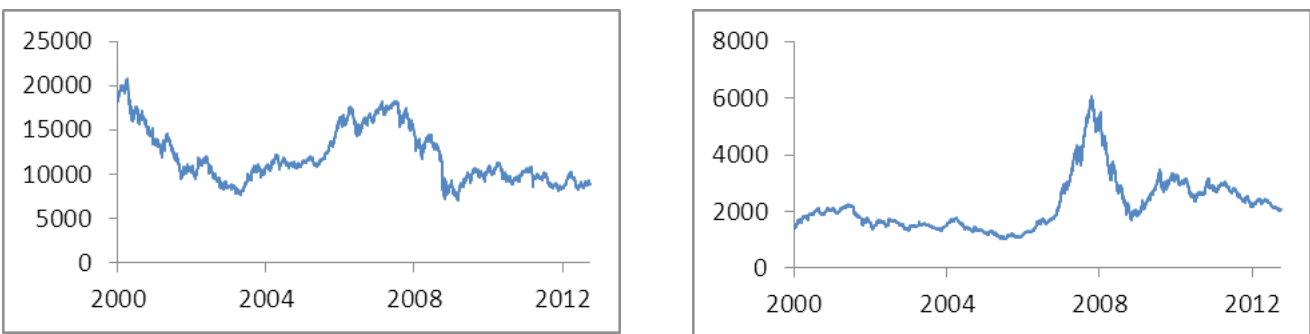

Indeks harga saham bursa Singapura

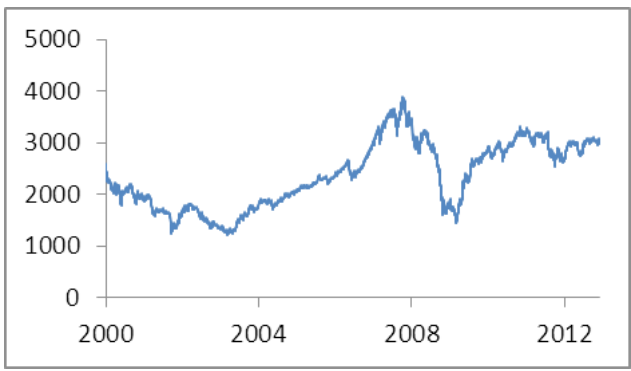

Tingkat imbal hasil harian dapat dilihat pada Grafik 2 dimana dapat terlihat bahwa pada seluruh bursa tingkat imbal hasil harian pada umumnya berkisar antara (terendah) rata-rata $-3 x$ deviasi standar sampai dengan (tertinggi) rata-rata $+3 x$ deviasi standar. Hal ini menarik karena besaran $5 \%$ adalah kurang lebih 3 kali besaran deviasi standar tingkat imbal hasil harian di masing-masing bursa, atau dengan kata lain, jika melihat sebagian besar rentang tingkat imbal hasil harian di masing-masing bursa, besaran tingkat imbal hasil adalah sesuai dengan rentang yang diramalkan oleh distribusi normal.

Tingkat imbalhasil saham bursa Hongkong

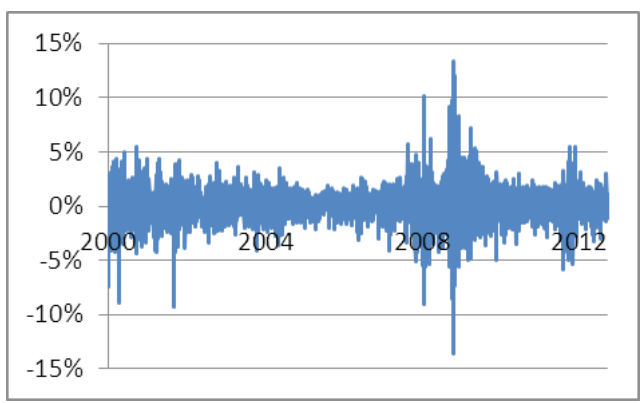

Tingkat imbal hasil saham bursa Malaysia

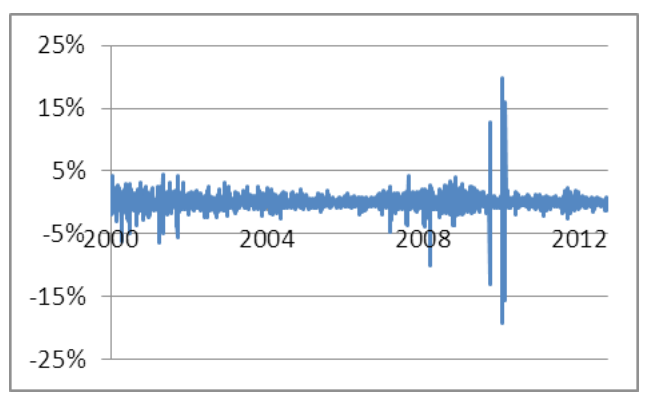

Tingkat imbal hasil saham bursa Jakarta

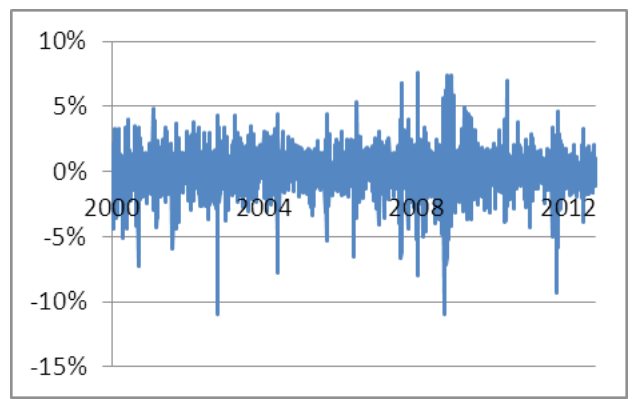

Tingkat imbal hasil saham bursa Korea

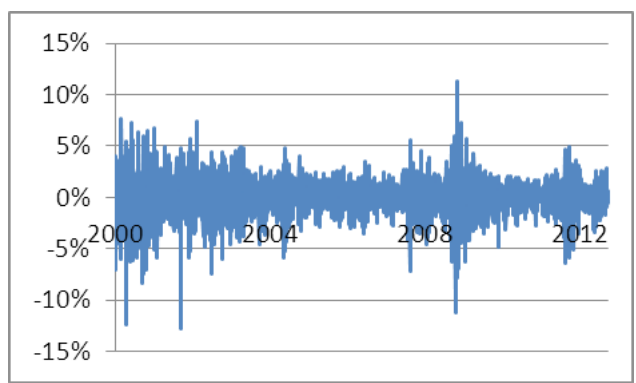


Tingkat imbal hasil saham bursa Jepang

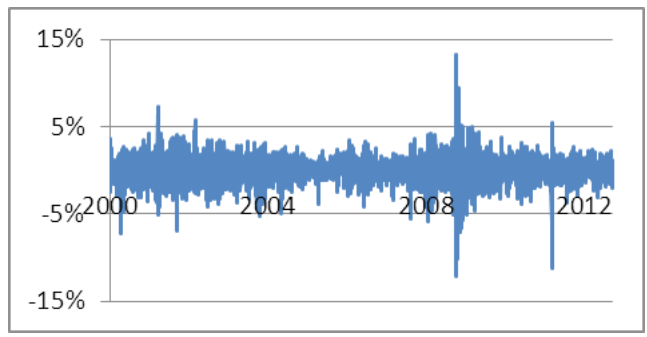

Tingkat imbal hasil saham bursa Singapura

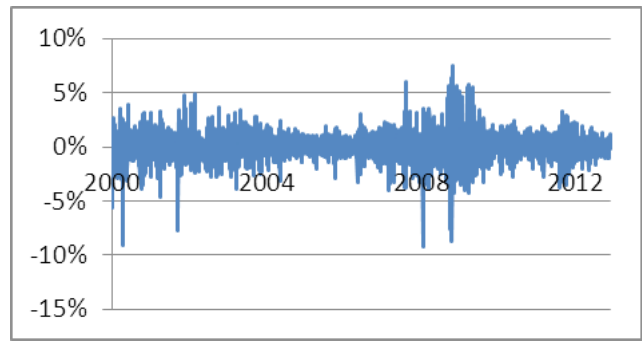

Tingkat imbal hasil saham bursa Shanghai

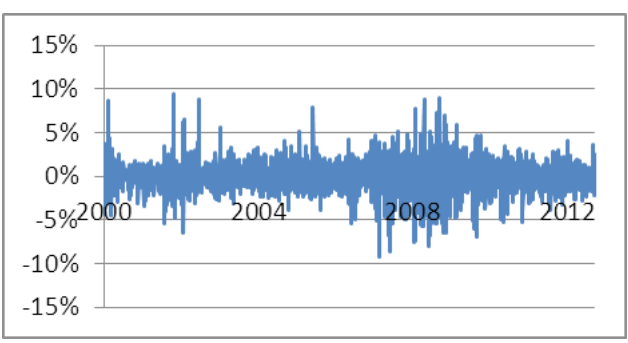

JURNAL

MANAJEMEN

INDONESIA

Vol. 14 - No. 1

April 2014

Berdasar Grafik 2 juga dapat terlihat bahwa pada setiap bursa terdapat saat-saat dimana tingkat imbal hasil harian berada lebih rendah dari $-5 \%$ ataupun lebih tinggi dari $+5 \%$. Tabel 2 menunjukkan gambaran mengenai berapa kali, persentase dari total hari pengamatan, dan secara rata-rata berapa hari sekali terjadi tingkat imbal hasil harian yang "ekstrim" - melewati batas 3 deviasi standar dari rata-rata - baik ke atas maupun ke bawah.

Berdasarkan hasil perhitungan, bursa di Singapura memiliki jumlah imbal hasil terbanyak yang meliwati batas positif (lebih besar dari 3 x deviasi standar) sebesar 21 hari atau sama dengan 0,64\% dari seluruh hari perdagangan. Jika dilihat dari persentasenya, hasil di Singapura adalah sama dengan hasil di bursa Korea, namun demikian, bursa Singapura masih memberikan hasil lebih tinggi di mana dengan besaran $0,64 \%$ berarti secara rata-rata bursa Singapura memberikan tingkat imbal hasil harian yang lebih tinggi dari 3 x deviasi standar setiap 156 hari sementara bursa Korea rata-rata memberikan tingkat imbal hasil yang lebih tinggi dari $3 \times$ deviasi standar setiap 158 hari. Bursa yang memberikan tingkat imbal harian yang lebih besar dari 3 deviasi standar tersedikit adalah Malaysia sebesar 0,25\% dari seluruh hari perdagangan atau setiap 392 hari sekali diikuti oleh Jepang sebesar 0,48\% atau setiap 209 hari.

Bursa yang terbanyak memberikan tingkat imbal hasil harian kurang dari $-3 \mathrm{x}$ deviasi standar adalah Shanghai di mana terdapat 32 kali tingkat imbal hasil harian yang lebih rendah dari-3 deviasi standar, setara dengan 0,98\% dari seluruh hari perdagangan atau 103 hari sekali, diikuti oleh bursa Korea yaitu 29 kali atau 0,92\% dari seluruh hari perdagangan atau setiap 109 hari. Bursa dengan tingkat imbal hasil harian lebih rendah dari-3 deviasi standar yang tersedikit adalah bursa Malaysia (19 kali yang berarti 0,61\% dari seluruh hari perdagangan atau rata-rata sekali setiap 166 hari), diikuti oleh bursa Singapura (24 kali, setara dangan 0,74\% dari seluruh hari perdagangan, setara dengan rata-rata sekali setiap 136 hari).

\begin{tabular}{|l|r|r|r|r|r|r|r|}
\hline & Hongkong & Indonesia & Malaysia & \multicolumn{1}{c|}{ Korea } & Jepang & \multicolumn{1}{c|}{ Shanghai } & Singapura \\
\hline \multirow{3}{*}{$\mathrm{R}<-3 S D$} & $28 \mathrm{kali}$ & $28 \mathrm{kali}$ & $19 \mathrm{kali}$ & $29 \mathrm{kali}$ & $27 \mathrm{kali}$ & $32 \mathrm{kali}$ & $24 \mathrm{kali}$ \\
\cline { 2 - 8 } & $0,88 \%$ & $0,91 \%$ & $0,61 \%$ & $0,92 \%$ & $0,86 \%$ & $0,98 \%$ & $0,74 \%$ \\
\cline { 2 - 8 } & $/ 113.57 \mathrm{hr}$ & $/ 110.21 \mathrm{hr}$ & $/ 165.21 \mathrm{hr}$ & $/ 108.45 \mathrm{hr}$ & $/ 115.85 \mathrm{hr}$ & $/ 102.13 \mathrm{hr}$ & $/ 135.67 \mathrm{hr}$ \\
\hline \multirow{3}{*}{$\mathrm{R}>3 S D$} & $18 \mathrm{kali}$ & $16 \mathrm{kali}$ & $8 \mathrm{kali}$ & $20 \mathrm{kali}$ & $15 \mathrm{kali}$ & $20 \mathrm{kali}$ & $21 \mathrm{kali}$ \\
\cline { 2 - 8 } & $0,57 \%$ & $0,52 \%$ & $0,25 \%$ & $0,64 \%$ & $0,48 \%$ & $0,61 \%$ & $0,64 \%$ \\
\cline { 2 - 8 } & $/ 176.67 \mathrm{hr}$ & $/ 192.88 \mathrm{hr}$ & $/ 392.38 \mathrm{hr}$ & $/ 157.25 \mathrm{hr}$ & $/ 208.53 \mathrm{hr}$ & $/ 163.40 \mathrm{hr}$ & $/ 155.05 \mathrm{hr}$ \\
\hline
\end{tabular}

Tabel 2

Tingkat Imbal Hasil yang "Ekstrim" $<-3$ Deviasi Standar dan $>+3$ Deviasi Standar 
JURNAL

MANAJEMEN

INDONESIA

Vol. 14 - No. 1

April 2014

Mencocokkan Distribusi Tingkat Imbal Hasil di Masing-Masing Bursa dengan Distribusi Teoretis

Dalam bagian ini, distribusi tingkat imbal hasil dari masing-masing bursa dicocokkan dengan distribusi teoretis. Pencocokan distribusi tingkat imbal hasil pertama-tama dilakukan antara distribusi tingkat imbal hasil dari setiap bursa dengan distribusi normal untuk mengetahui apakah distribusi tingkat imbal hasil dari masing-masing bursa adalah sesuai dengan distribusi normal atau tidak. Hasil pencocokkan tersebut dapat dilihat pada Grafik 3.

Distribusi aktual vs normal - bursa Hongkong

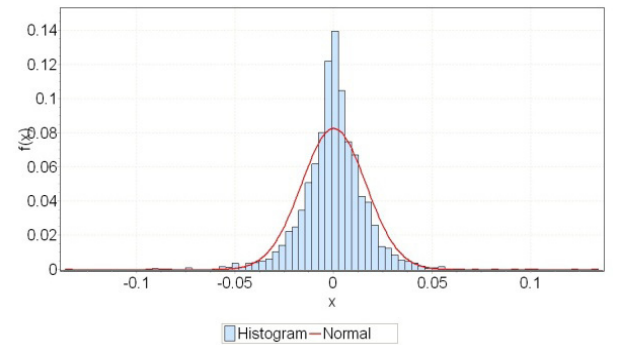

Distribusi aktual vs normal - bursa Malaysia

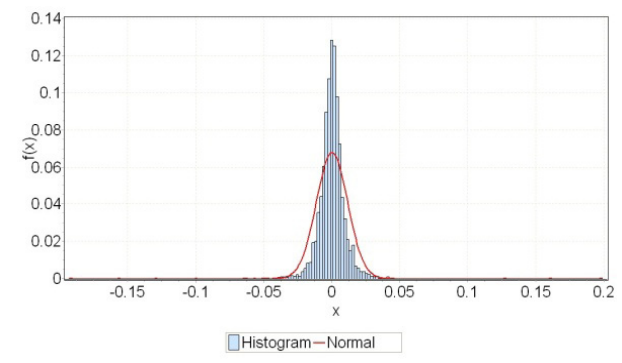

Distribusi aktual vs normal - bursa Jepang

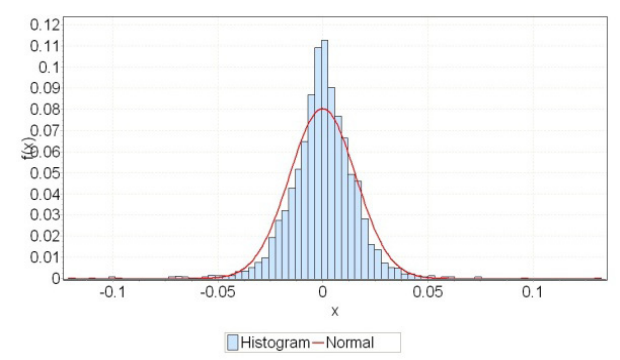

Distribusi aktual vs normal - bursa Singapura

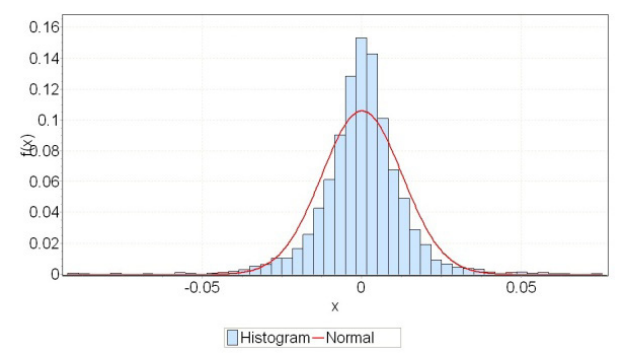

Distribusi aktual vs normal - bursa Indonesia

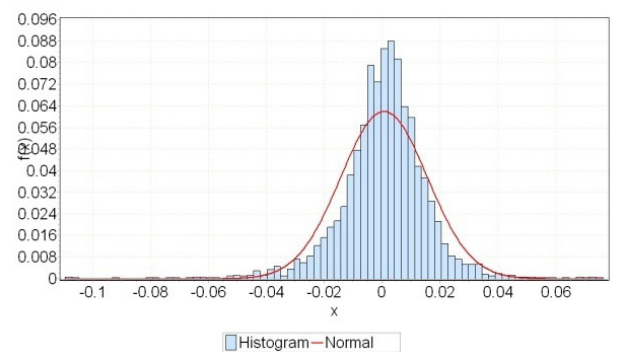

Distribusi aktual vs normal - bursa Korea

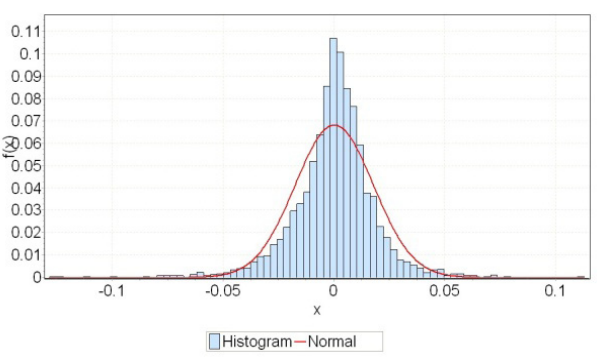

Distribusi aktual vs normal - bursa Shanghai

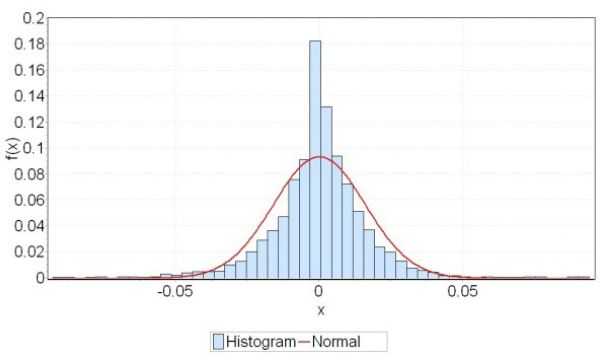

Grafik 3

Hasil Pencocokan Distribusi Tingkat Imbal Hasil MasingMasing Bursa dengan Distribusi Normal 
Berdasar Grafik 3 dapat dilihat bahwa distribusi tingkat imbal hasil dari masing-masing bursa cenderung lebih ramping dari distribusi normal dan bersifat leptokurtik. Dengan demikian dapat diperkirakan bahwa distribusi tingkat imbal hasil dari bursa-bursa yang diamati tidak mengikuti distribusi normal.

Penentuan distribusi tingkat imbal hasil yang sesuai dilakukan dengan mencocokkan distribusi tingkat imbal hasil yang ada dengan berbagai distribusi teoretis. Hasil pencocokan distribusi dapat dilihat pada Tabel 3:

\begin{tabular}{|l|l|}
\hline \multicolumn{1}{|c|}{ Bursa } & \multicolumn{1}{c|}{ Distribusi yang sesuai } \\
\hline Hongkong & Laplace \\
\hline Indonesia & Johnson SU \\
\hline Malaysia & Johnson SU \\
\hline Korea & Johnson SU \\
\hline Jepang & Johnson SU \\
\hline Shanghai & Laplace \\
\hline Singapura & Johnson SU \\
\hline
\end{tabular}

Dari Tabel 3 terlihat bahwa distribusi tingkat imbal hasil harian di bursa Hongkong dan Shanghai cocok dengan distribusi Laplace. Karena distribusi Laplace adalah distribusi yang simetris dan memiliki ekor tebal, maka dapat disimpulkan juga bahwa distribusi tingkat imbal hasil harian di bursa Hongkong dan Shanghai selama masa pengamatan adalah simetris dan memiliki ekor tebal. Distribusi tingkat imbal hasil harian untuk bursa-bursa Indonesia, Malaysia, Korea, Jepang, dan Singapura adalah cocok dengan distribusi Johnson SU. Hasil pencocokan distribusi tingkat imbal hasil di setiap bursa dengan distribusi teoretis yang sesuai ditunjukkan pada Grafik 4:

Bursa Hongkong - Laplace

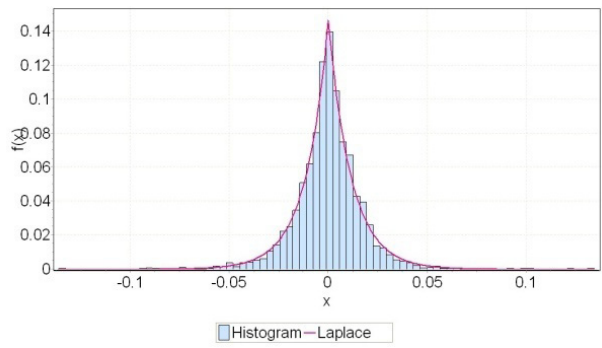

Bursa Malaysia - Johnson SU

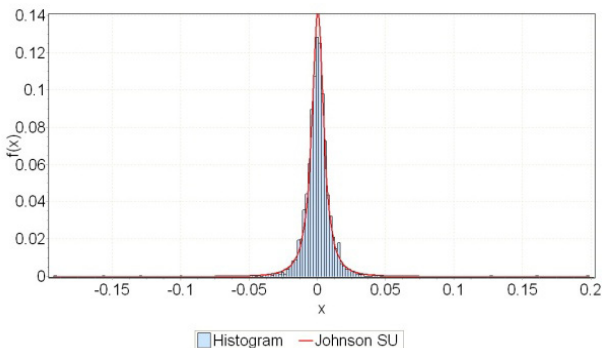

Bursa Indonesia - Johnson SU

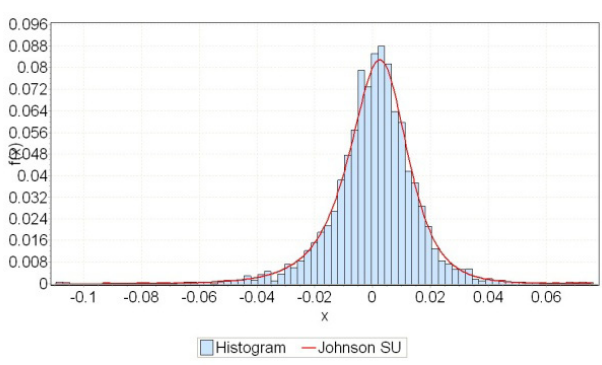

Bursa Korea - Johnson SU

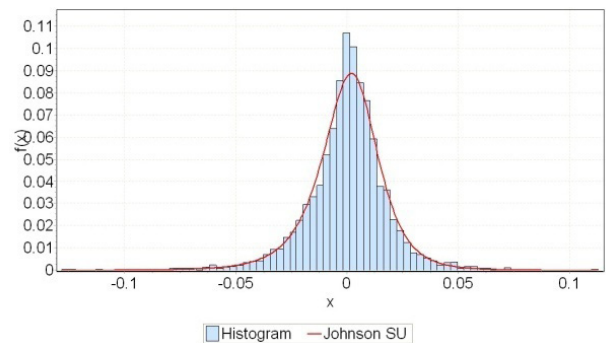

Tabel 3

Distribusi Teoretis yang Sesuai dengan Distribusi Tingkat Imbal Hasil untuk Setiap Bursa

Grafik 4

Pencocokan Distribusi Tingkat Imbal Hasil Adi Setiap Bursa dengan Distribusi Teoretis yang Sesuai 
Bursa Jepang - Johnson SU

JURNAL

MANAJEMEN

INDONESIA

Vol. 14 - No. 1

April 2014

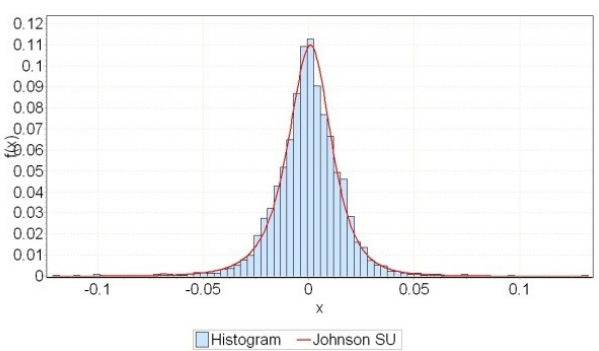

Bursa Singapura - Johnson SU

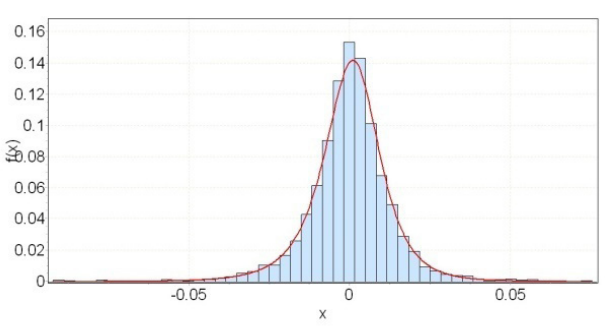

$\square$ Histogram - Johnson SU
Bursa Shanghai - Laplace

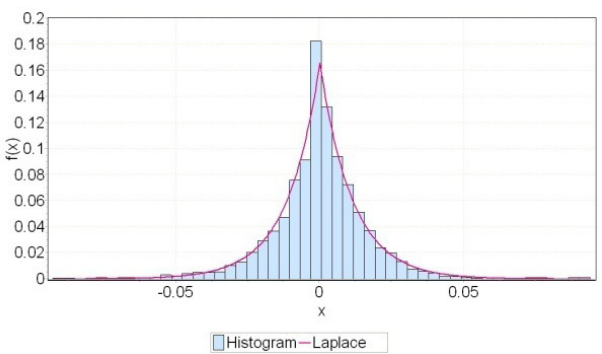

\section{Besaran Parameter hasil Estimasi Distribusi yang Sesuai untuk Masing-Masing Bursa}

Parameter hasil estimasi distribusi Laplace untuk bursa Hongkong dan bursa Shanghai dapat dilihat pada Tabel 4.

Tabel 4

\begin{tabular}{|c|c|c|}
\hline \multirow{2}{*}{ Bursa } & \multicolumn{2}{|c|}{ Parameter } \\
\cline { 2 - 3 } & Lokasi & Skala (invers) \\
\cline { 2 - 3 } & $\mu$ & $\lambda$ \\
\hline Hongkong & $5.7286 \mathrm{E}-5$ & 86.7070 \\
\hline Shanghai & $1.2944 \mathrm{E}-4$ & 88.6197 \\
\hline
\end{tabular}

Berdasar parameter hasil estimasi yang terdapat pada Tabel 4 terlihat besaran $\mu$ untuk bursa Hongkong adalah 5,7286×10-5 atau sekitar 0,06\%, sesuai dengan rata-rata tingkat imbal hasil harian untuk bursa Hongkong sebesar $0,06 \%$ sementara itu besaran $\mu$ untuk bursa Shanghai adalah $0,013 \%$, sesuai dengan rata-rata tingkat imbal hasil harian untuk bursa Shanghai. Untuk lokasi, hasil estimasi $\lambda$ untuk skala di Tabel 4 adalah sekitar 2,72\% untuk bursa Hongkong dan $2,71 \%$ untuk bursa Shanghai. Dalam kenyataannya, terdapat perbedaan dari hasil estimasi yaitu 1,631\% untuk bursa Hongkong dan 1,596\% untuk bursa Shanghai.

Parameter distribusi Johnson SU untuk bursa-bursa selain Hongkong dan Shanghai dapat dilihat pada Tabel 5.

Tabel 5

Parameter Distribusi Johnson SU untuk Bursa-Bursa selain Hongkong dan Shanghai

\begin{tabular}{|l|c|c|c|c|}
\hline \multirow{2}{*}{ Bursa } & \multicolumn{4}{|c|}{ Parameter } \\
\cline { 2 - 5 } & Lokasi & Skala & Kemencengan & Kurtosis \\
\cline { 2 - 5 } & $\xi$ & $\lambda$ & $\gamma$ & $\delta$ \\
\hline Indonesia & 0.0044 & 0.0154 & 0.2678 & 1.3904 \\
\hline Malaysia & 0.0004 & 0.0048 & 0.0160 & 0.8915 \\
\hline Korea & 0.0041 & 0.0195 & 0.2267 & 1.4503 \\
\hline Jepang & 0.0017 & 0.0153 & 0.1270 & 1.3290 \\
\hline Singapura & 0.0019 & 0.0129 & 0.1520 & 1.3755 \\
\hline
\end{tabular}


Berdasar parameter hasil estimasi yang terdapat pada Tabel 5 terlihat besaran $\xi$ untuk setiap bursa cenderung berbeda dari rata-rata tingkat imbal hasil harian untuk setiap bursa dengan selisih estimasi terkecil adalah di bursa Malaysia. Namun demikian, estimasi deviasi standar cenderung sesuai dengan data distribusi tingkat imbal hasil harian yang ada dengan selisih sekitar $2 \%$ kecuali untuk bursa Malaysia - selisih sampai dengan $130 \%$ dan Korea sebesar 10\%. Selain itu estimasi parameter menunjukkan adanya sedikit kemencengan positif dengan kemencengan terbesar terdapat di bursa Indonesia dan diikuti oleh bursa Korea. Kemencengan terkecil terdapat di bursa Malaysia.Untuk parameter kurtosis, dapat terlihat bahwa data bersifat leptokurtik dengan keruncingan tertinggi terdapat di bursa Korea dan terendah adalah di bursa Malaysia.

\section{PEMBAHASAN}

Hasil perhitungan tingkat imbal hasil harian menunjukkan bahwa bursa Indonesia memiliki tingkat imbal hasil harian yang tertinggi dari seluruh bursa yang diteliti sementara yang terendah adalah bursa Jepang. Deviasi standar tertinggi terdapat di Korea sementara terendah adalah Malaysia. Tingkat imbal hasil harian yang tertinggi dan terendah diberikan oleh bursa Malaysia. Sebagian besar tingkat imbal hasil diseluruh bursa berada pada rentang yang diperkirakan oleh distribusi normal - berada dalam rentang -3 deviasi standar sampai dengan +3 deviasi standar dari rata-rata, namun terdapat beberapa tingkat imbal hasil yang "ekstrim" karena lebih rendah dari -3 deviasi standar ataupun di atas +3 deviasi standar dari rata-rata. Bursa yang paling banyak memberikan tingkat imbal hasil harian di atas +3 deviasi standar dari rata-rata adalah Singapura sementara yang tersedikit adalah Malaysia. Bursa yang paling banyak memberikan tingkat imbal hasil harian di bawah -3 deviasi standar adalah Shanghai dan yang tersedikit adalah Malaysia. Seluruh bursa memiliki kecenderungan leptokurtik dan setelah diuji lebih jauh, tingkat imbal hasil harian di bursa Hongkong dan Shanghai adalah mengikuti distribusi Laplace sementara tingkat imbal hasil harian di bursa-bursa Jakarta, Malaysia, Korea, Jepang, dan Singapura adalah mengikuti distribusi Johnson SU.

Hasil dari penelitian ini dapat digunakan untuk penelitian selanjutnya. Distribusi Laplace dan Johnson SU adalah distribusi yang memiliki ekor tebal sehingga untuk penelitian berikutnya dapat dilakukan sebagai dengan memanfaatkan ketebalan ekor dari distribusi Laplace dalam konteks pemodelan GARCH dan menggunakan ekor dari distribusi Johnson SU untuk melakukan perhitungan value at risk.

\section{DAFTAR PUSTAKA}

Azzalini, A. and A. Capitanio (2003); Distributions generated by perturbation of symmetry with emphasis on a multivariate skew t-distribution. Journal of the Royal Statistical Society, Series B: Statistical Methodology 65 (2), 367-389.

Bachelier, L. (1900a); Théorie de la spéculation, Annales Scientifiques de l'École Normale Supérieure 3 (17): 21-86

Balakrishnan, N., dan V. B. Nevzorov (2003); A Primer on Statistical Distributions, New Jersey, John Wiley and Sons

Barndorff-Nielsen, O. E., (1997); Normal inverse Gaussian distributions and stochastic volatilitymodeling. Scandinavian Journal of Statistics 24, 1-13.

Bollerslev, T. (1987); A conditionally heteroskedastic time series model for speculative prices and rates of return. The Review of Economics and Statistics 69, 542-547.

Campbell, John Y., Andrew W. Lo, dan A. Craig MacKinlay (1997); The Econometrics of Financial Markets, Princeton University Press

Clark, Peter C. (1973); A Subordinated Stochastic Process Model with Finite Variance for Speculative Prices, Econometrica, Vol. 41, No. 1. (Jan., 1973), hal. 135-155. 
Cont, R., (2001); Empirical properties of asset returns: stylized facts and statistical issues, Quantitative Finance, Vol. 1, hal 223-226

JURNAL MANAJEMEN INDONESIA

Vol. 14 - No. 1 April 2014

Cont, R., M. Potters dan J-P Bouchaud (1997); Scaling in stock market data: stable laws and beyond Scale Invariance and Beyond (Proc. CNRS Workshop on Scale Invariance, Les Houches, 1997) ed Dubrulle, Graner and Sornette (Berlin: Springer)

Eberlein, E. andU. Keller (1995); Hyperbolic distributions in finance. Bernoulli 1, 281-299.

Fama, E.F. (1965);The behavior of stock market prices, Journal of Business 38: 34-105.

Fernández, C. and M. F. J. Steel (1998); On Bayesian modeling of fat tails and skewness,Journal of the American Statistical Association 93, 359-371

González-Rivera, G. (1997), A note on adaptation in GARCH models, Econometric Reviews 16 (1), 55-68.

Granger, C. and Ding, Z. (1995), Some properties of absolute return, an alternative measure of risk, Annales d'Economie et de Statistique 40, 67-91.

Hansen, B., (1994); Autoregressive conditional density estimation. International Economic Review 35, 705-730.

Harvey, C. R. andA. Siddique (1999); Autoregressive conditional skewness. Journal of Financial and Quantitative Analysis 34 (4), 465-487.

Harvey, C. R. and A. Siddique (2000); Conditional skewness in asset pricing tests. Journal of Finance 55 (3), 1263-1295.

Johnson, N.L.(1949). Systems of frequency curves generated by methods of translation. Biometrika 36, 149-176.

Johnson N.L, S. Kotz S. and N. Balakrishnan (1995). Continuous Univariate Distributions, Volume 2. New York: Wiley

Jondeau, E., andM. Rockinger (2001); Gram-charlier densities,Journal of Economic Dynamics and Control 25 (10), 1457-1483.

Jones, M. C., and M. J. Faddy (2003); A skew extension of the t-distribution, with applications. Journal of the Royal Statistical Society, Series B: Statistical Methodology 65 (1), 159-174

Kendall, M. G. dan A. Bradford Hill (1953); The Analysis of Economic Time-Series- Part I: Prices, Journal of the Royal Statistical Society. Series A (General), Volume 116, Issue1: 11 - 34

Koponen, I. (1995); Analytic approach to the problem of convergence of truncated Levy flights towards the Gaussian stochastic process, Physical Review E 52: 1197-1199.

Malkiel, Burton, G. (1987); Efficient Market Hypothesis, The New Palgrave: A Dictionary of Economics, Vol. 2: 120-23.

Mandelbrot, B.B. (1963); The variation of certain speculative prices, Journal of Business 36: 394-419.

Mantegna, R.N. and H. E. Stanley (1994);Stochastic processes with ultraslow convergence to a Gaussian: The truncated Lévy flight, Physical Review Letters 73: 2946-2949

McCulloch, J. H.(1996);Financial applications of stable distributions. In: Maddala, G. S., Rao,C. R. (Eds.), Handbook of Statistics Volume 14: Statistical Methods in Finance. Elsevier/ North-Holland [Elsevier Science Publishing Co., New York; North-Holland Publishing Co., Amsterdam], 393-425.

Mittnik, S. and S. Rachev(1993), Modeling asset returns with alternative stable distributions, EconometricReviews 12, 261-330.

Mittnik, S., Marc S. Paolella, and Svetlozar T. Rachev (1998); Unconditional and Conditional Distributional Models for the Nikkei Index, Asia-Pacific Financial Markets 5: 99-128,

Nelson, D. B., 1991. Conditional heteroskedasticity in asset returns: A new approach. Econometrica 59, 347-370.

Osborn, M. F., (1959) Brownian Motion in the Stock Market", Operations Research, vol. 7, 145173.

Peters, Edgar (1991) Chaos and Order in Capital Markets, A New View of Cycles, Prices, and Market Volatility, John Wiley \& Sons, New York 
Rachev, S dan S. Mittnik. (2002) Stable Paretian models in Finance. John Wiley\&Sons, N.Y.

Samorodnitsky, G dan M.S. Taqqu, 1994, Stable Non-Gaussian Random Processes, Stochastic Models with Infinite Variance. Chapman and Hall: New York and London

JURNAL

MANAJEMEN

Srivastava, H.M., Saralees Nadarajah, and Samuel Kotz (2006); Some generalizations of the Laplace distribution, Applied Mathematics and Computation 182, 223-231

INDONESIA

Working, H. (1934), A Random-Difference Series for Use in the Analysis of Time Series, Journal of the American Statistical Association, Volume 29, Issue 185 (Mar., 1934): 11 - 24

Vol. 14 - No. 1 April 2014

Yan, Jun (2005); Asymmetry, Fat-tail, and Autoregressive Conditional Density in Financial Return Data with Systems of Frequency Curves, Working Paper, University of lowa 